\title{
The Embryo Malpositions in Pekin Dwcik Eggs
}

G.A.R. Kamar, H. H. Hussain, L. Goher, and M. M. El Nadi

Faculty of Agriculture, Cairo and Menofia Universities

Egypt.

DEKIN duck eggs were used in studying the embryo malpositions, The experiment was carried under the usual system of mating and nutrition in the Ponliny Research Station, Faculty of Agriculture, Cairo University.

The study included $3748 \mathrm{eggs}, 2151 \mathrm{cggs}$ in the first year (from January to May), and 1597 eggs in the second year (from Jandary to April).

The embryo malposition in Pekin duck eggs were malpositions type 2 (head is found in the small end of the egg), type 3 (head to left side), typo 5 (fcet over hond), type 7 (body across the egg) and combination of type $2+1$ and $2+3$. Malposition of type 4 . (the beak is not directed toward the air cell), and type 6 (beak above rightwing) were not found. Malposition 3 was the most frequent $(83.99 \%$ of the total number of maiposition) followed by type $2(13.59 \%)$, type $5(1.38 \%)$ type $7(0.81 \%)$ and combination of type $2+1$ and $2+3(0.12 \%$ for each).

There were not any appreciable effect of egg measurcments or egg index on embryo malposition.

Among embryos which failed to hatch, more than 50 percent were found to be in position different from normal just previous to hatching (Senctuary, $1924,1925)$. Half of the embryos that die after the eighteenth day of development or that fail to hatch are in malpositions.

This constitutes approximately one-fourth of the total embryonic mortality (Sanctuary, 1925; Smith, 1931, Hutt and Cavers, 1931 and Byerly and Olsen, 1935 a) Sanctuary (1925) and Helmy (1958) reported that malposition I (head between thighs) is the most frequent, while Hutt (1929), and Byerly and Olsen $(1933,1936$ b) found that malposition 2 (head in the small end, was more frequent reaching about $25.7 \%$ of the total malposition, and malposition I had the least frequency as it cormprised about $0.6 \%$ only of the total malposition.

Among eggs incubated horizontally, malposition 2 and 4 (embryo rotated that beak is not direct towards the air cell) were more frequent (Byerly and Olsen, 1936 b) Malposition are not all a direct cause of death or failure of hatching (Byerly and Olsen, 1934). Some malposition may be the result of death or delayed development. 
Malposition 1 is always lethal, while chicks in other malposition $(2,3,4$ and 6) sometimes pip and hatch. Embryos rarely pip the shell when they are in malposition 3 or in combination of 1 and 2 or 2 and 2, (Asmundson, 1938).

Some of the malpositions are the normal position of the embryo at certain age (Waters, 1935). He found that the majority of the embryos were in malpositions during approximately the eighteinth day of incubation and if embryonic death occurs during this period, the embryo will not probably be in the normal hatching position.

The position of the eggs during incubation, the number of egg tuming size of the egg and temperature were found to effect the incidence of the different types of malpositions.

Malposition 2 and 4 are common among horizontally incubated egg than among those incubated with the large end up, whereas the reverse is true for malposition 3 (Byerly and Olsen, 1936 b).

High incubation temperature was found to raise the frequency of malposition 1 and 2, where as malposition 2 was found to be more than ordinarly common at temperature below as well as above the optimum (Byerly, 1938).

Frequent turning of the eggs during incubation tends to reduce the incidence of malposition (Insko and Martin, 1933, Olsen and Byerly, 1936).

Malposition 3, occurred more frequently in large eggs than in small ones (Hutt, 1938), but there is no significant difference in this respect (Asmundson, 1935).

Few abnormal, embryos occurred in eggs which had been turned hourly than in those turned 3 times every day, but the difference did not reach significance (Visschedijk and Kuiper, 1955).

Malposition may be genetically conditioned as its incidence is greater in eggs of certain hans, or in eggs of some breeds, it may result from inbreeding. Non-genetic causes are also mentioned (Hoogendoorn, 1955).

\section{Material and Methods.}

The study was carried out at the Poultry Research Station, Faculty of Agriculture, Cairo University.

The work has been done on the White Pekin duck (Anas playtrhynchos) through two successive hatching seasons. The first season was during the period from January to May and the second was from January to April the next year.

Egypt. J. Anim. Prod. 24, No. 1-2 (1984) 
Eggs were collected and kept for a period not less than $24 \mathrm{hr}$, and not more than 7-10 days.

Before incubation they were given a serial number, and measured for the two axis to detect the egg index $\left(\frac{\text { width }}{\text { length }} \times 100\right)$. The eggs were candeled to exclude the unsuitable ones for incubation (invisible crack, malposition of the air space and porosity of the egg shell.

Throughout the incubation period, endling was performed twice : at the 8 th and 22 day of incubation. Dead and unhatched embryos were examined to determine their age and to detect their abnormalities.

Embryos that were not in the normal position (Head under the right wing) were detected and recorded a malposition.

The malpositions were classified to seven types as follows, which is accepted by the majority of research workers (Sancturary 1925, Hutt 1929, Smith 1931 and Landauer, 1948).

Malposition 1 : Head between thighs.

Malposition 2 : Head in small end of the egg.

Malposition 3: Head to left instead of under right wing.

Malposition 4 : Embryos rotated in such away that the beak is not directed towards the air cell.

Malposition 5 : Feet over head.

Malposition 6: Beak above right wing instead of underneath it.

Malposition 7 : Embryos across the egg.

Malpositions were estimated in percent of the total dead embryos and of the total in shell at the 28th day of incubation. The frequency of each type of the seven embryo malpositions was estimated in percent of the total number of malpositions.

Analysis of variance was carried out according to Snedecor (1956) for testing the differences in embryonic malpositions between years and months.

\section{Results and Discussion} tion.

Among the dead and unhatched embryos some can be found in malposi-

Egypt. J. Anim. Prod. 24, No. 1-2 (1984) 
As appears from Table 1 only $36.90 \%$ of the dead embryos were in malpositions $(36.64 \%$ and $37.32 \%$ in the first and sccond year respectively).

\begin{tabular}{|c|c|c|c|c|c|c|}
\hline \multirow{2}{*}{ Years } & \multirow{2}{*}{$\begin{array}{l}\text { No. of } \\
\text { egg set }\end{array}$} & \multirow{2}{*}{$\begin{array}{l}\text { No. of } \\
\text { dead } \\
\text { embryos }\end{array}$} & \multirow{2}{*}{$\begin{array}{c}\text { No.of } \\
\text { degd } \\
\text { ist-shells }\end{array}$} & \multirow{2}{*}{$\begin{array}{l}\text { No. of } \\
\text { malpo- } \\
\text { sitions }\end{array}$} & \multicolumn{2}{|c|}{$\%$ Mapposition } \\
\hline & & & & & $\begin{array}{l}\text { of dirad } \\
\text { embryos }\end{array}$ & $\begin{array}{c}\text { of dead-in } \\
\text { shells }\end{array}$ \\
\hline $\begin{array}{l}1971 \\
1972 \\
\text { otal }\end{array}$ & $\begin{array}{l}2151 \\
1597 \\
3748\end{array}$ & $\begin{array}{r}1933 \\
919 \\
2352\end{array}$ & $\begin{array}{r}730 \\
460 \\
1190\end{array}$ & $\begin{array}{l}525 \\
343 \\
868\end{array}$ & $\begin{array}{l}36.64 \\
37.32 \\
36.90\end{array}$ & $\begin{array}{l}70.82 \\
74.57 \\
72.95\end{array}$ \\
\hline
\end{tabular}

These percentages reached about $72.95 \%$ of the dead-in-shell $(70.82 \%$, $74.57 \%$ for the two years, respectively). These results were higher than those found in chicks by Eyerly and Olsen (1936 a) who found that malpositions were about $25 \%$ of all the dead embryos. Sanctizary (1925) in chicks also found that half of the dead in-shell only were in malposition.

The types of malpositions occurred in this study and their percentage are given in Table 2 ,

It was found that malpositions found in Pekin duck eggs were malposition of type 2 (head is found in small end of the egg), malposition 3 (head to left instead of under right wing), malposition 5 (feet over head) and malposition 7 (Body across the egg). In two cases, the embryos had a combination of two types of malpositions together (malpositon $1+3$ and malposition $2+-3$ ). Malposition 4 (Embryo rated in such away that the beak is not directed towards the air cell), and malposition 6 (Beak above right wing instead of underneath it) were not found in this experiment.

Malposition 3 was the most frequent type. It had an average frequency of $83.99 \%$ of the total number of malpositions in the two years $(82.48 \%$ in the first year and $86.30 \%$ in the second year).

Type 2 was less frequent than type 3 , followed by type 7 , type 5 , type 3 combined with type 1 and type 2 . Their frequencies were $13.59,1.38,0.81$, 0.12 and $0.12 \%$ of the total number of malpositions for type $2,7,5,3 \mathrm{combi-}$ ned with 1 and 3 combined with 2 , respectively

The results contradic those obtained by Sanctury (1925) and Helmy (1958) in chicks. They reported that malposition I was the most frequent followed by malposition 2. The findings that described by Amer and $\mathrm{E}$. Mahdy (1963) are in agreement with the present study. They found that malposition 3 was the most frequent type. Beside the above mentioned results, Byerly and Olsen (1936b) and Amer (1952), reported that type 2 was more frequent than type 1.

Egypt. J. Anim. Prod. 24, No. 1-2 (1984) 
THE EMBRYO MALPOSITIONS IN PEKIN DUCK EGGS.

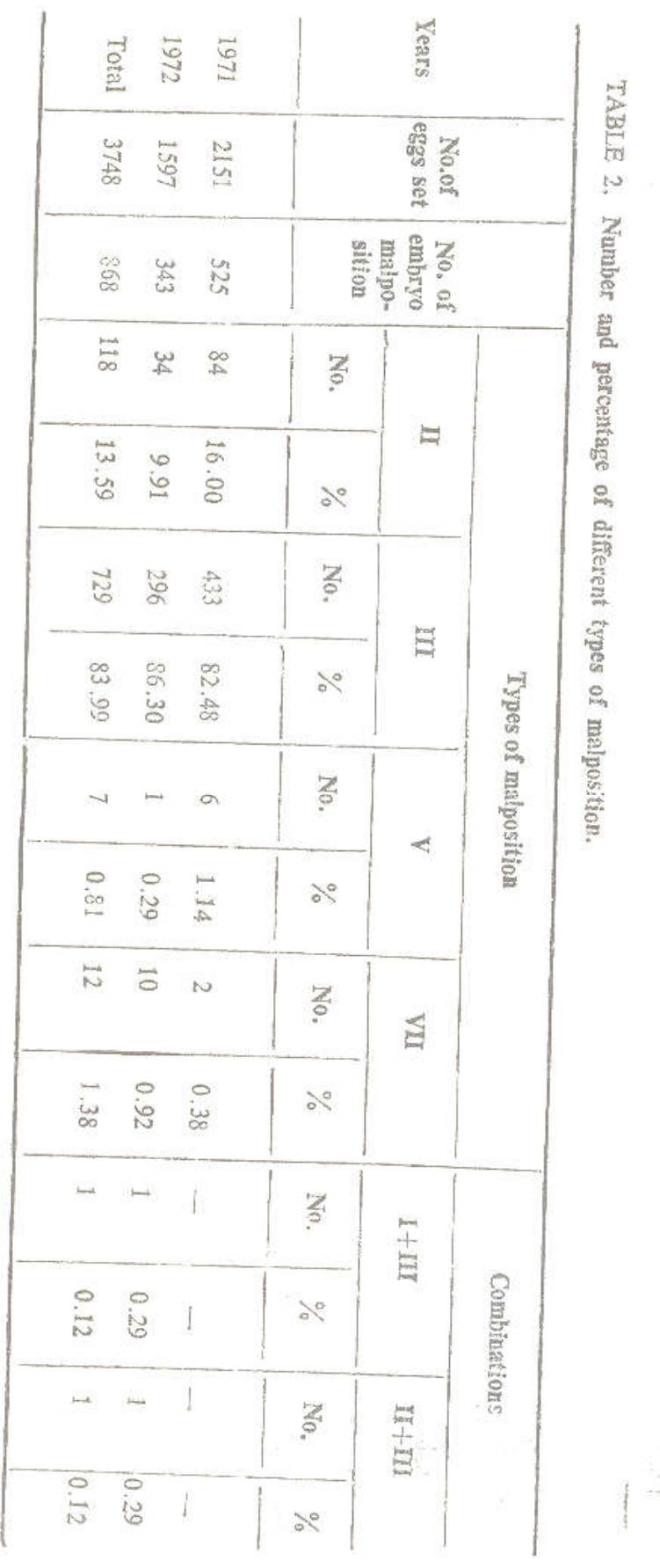

Egypt. J. Anim. Prod. 24, No. 1-2 (1984) 


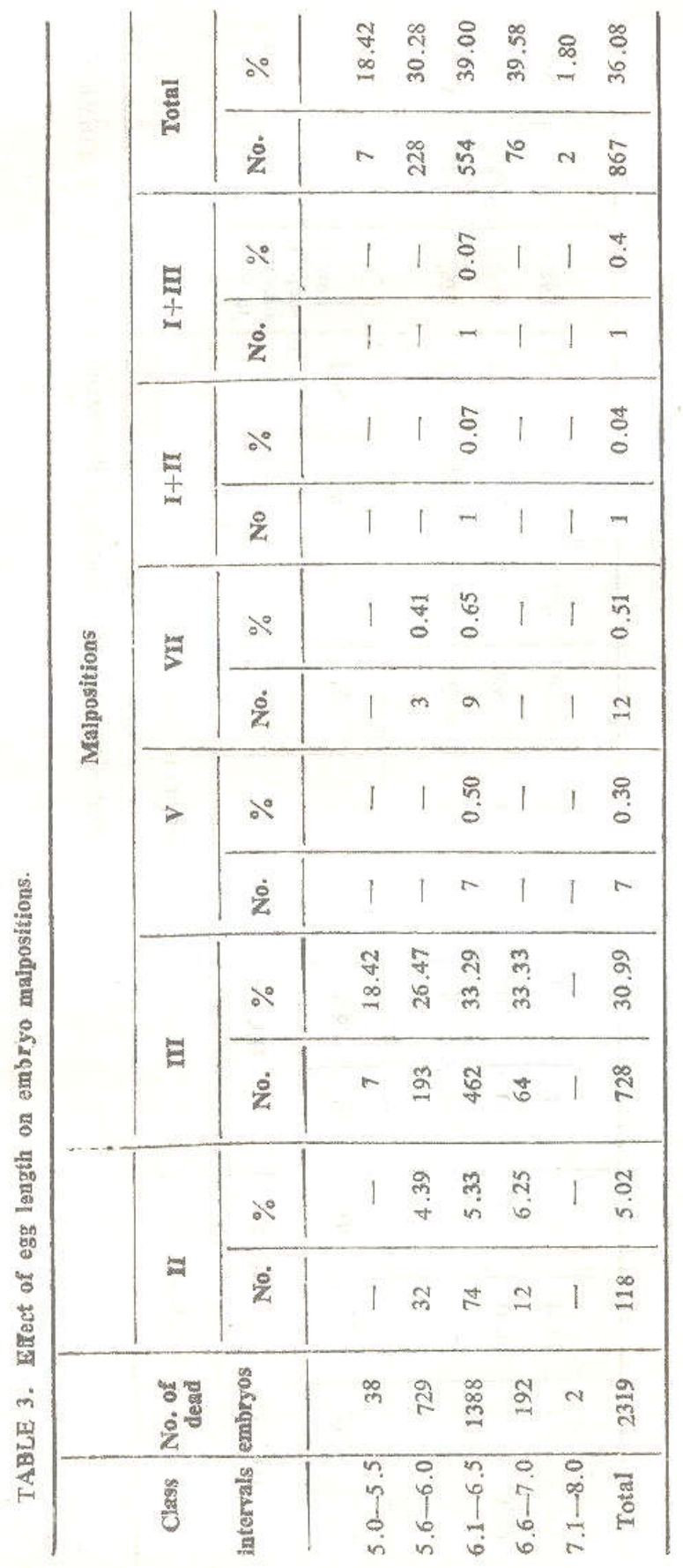

Egypt. J. Anim. Prod. 24, No. 1-2 (1984) 
THE EMBRYO MALPOSITIONS IN PEKIN DUCK EGGS.

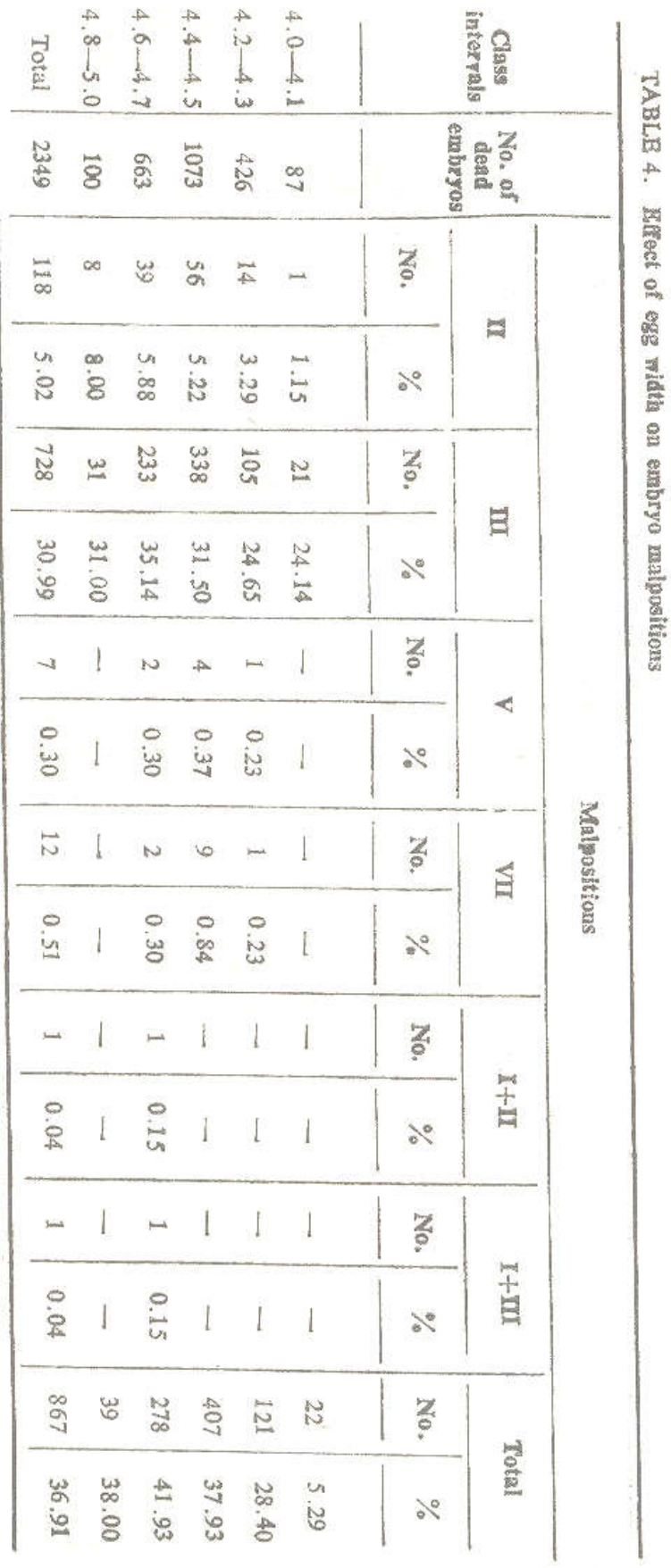

Eeyp. J. Anim. Prod. 24, No. 1-2 (1984) 


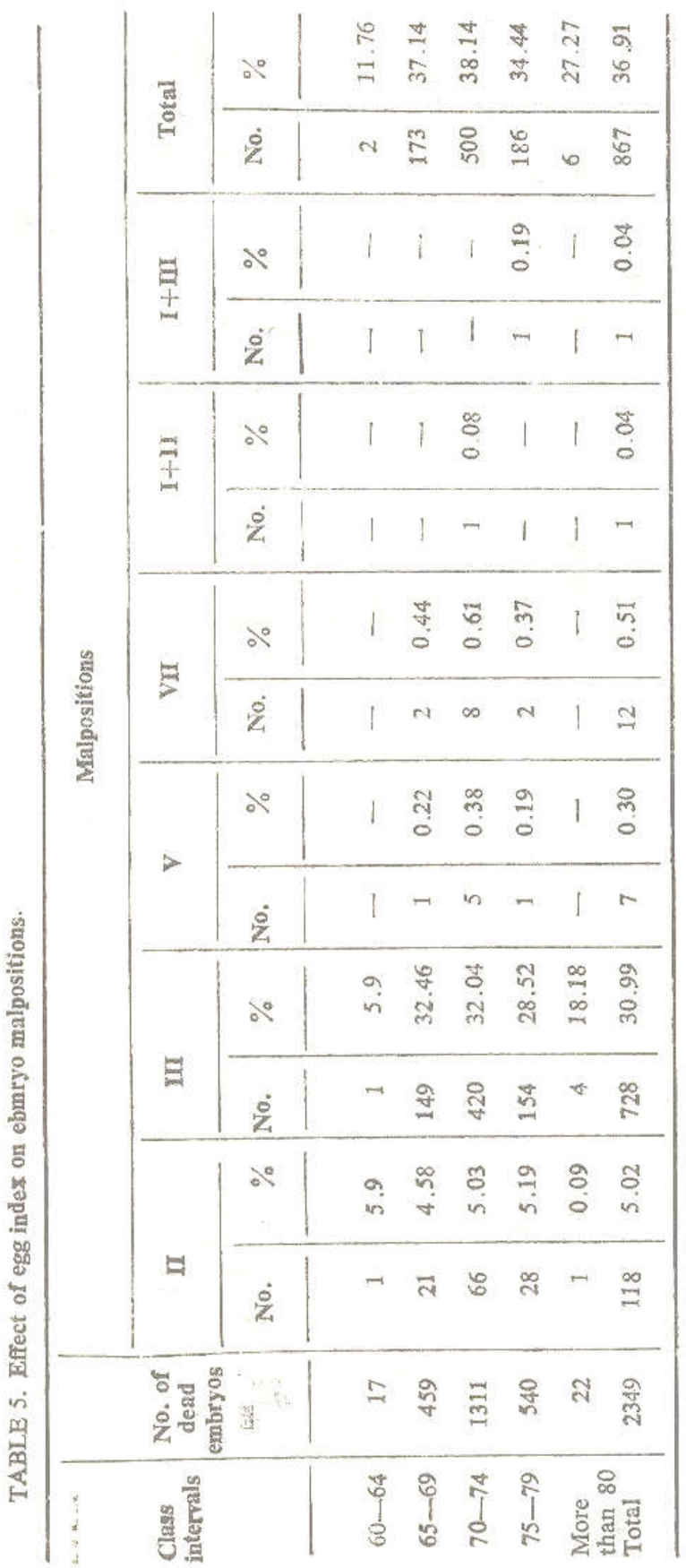

Egypt. J. Anim. Prod. 24, No, 1-2 (1984) 
In accordance with the present results, Amer and El-Mahdy (1963) found 1key (1934) and Cavers and found in Dandarawi. Hutt (1929), Hutt and Pi6 hatch in some cases.

The differences in the results obtained by those workers may be due to dififerences in species and even in breeds. The differences also may be due to diferences in the hereditary factors, management conditions of the due to position of the eggs in the trays during the incubation eggs and temperature in the incubation.

Byerly (1938) stated that high incubation temperature was found to raise the frequency of malposition 1 and 3 . In additionerature was found to raise Hutt and Pilkey (1934), and Byeriy and In addition, Insko and Martin (1933), ition 3 is more frequent among eggs in olsen (1936a) reportcd that malposthose incubated horizontaily and the incidented with large-end-up than among ined during the second week of incidence of malposition 4 is determin malposition 3 by Byeriy and Olsen $(1933)$ The same result is obtained

The effect of egg measurements and egg index on embryos malpiositons were studied.

The results were as shown in Tables 3,4 and $5 . s$ It can be seen that there bryo malpositions.

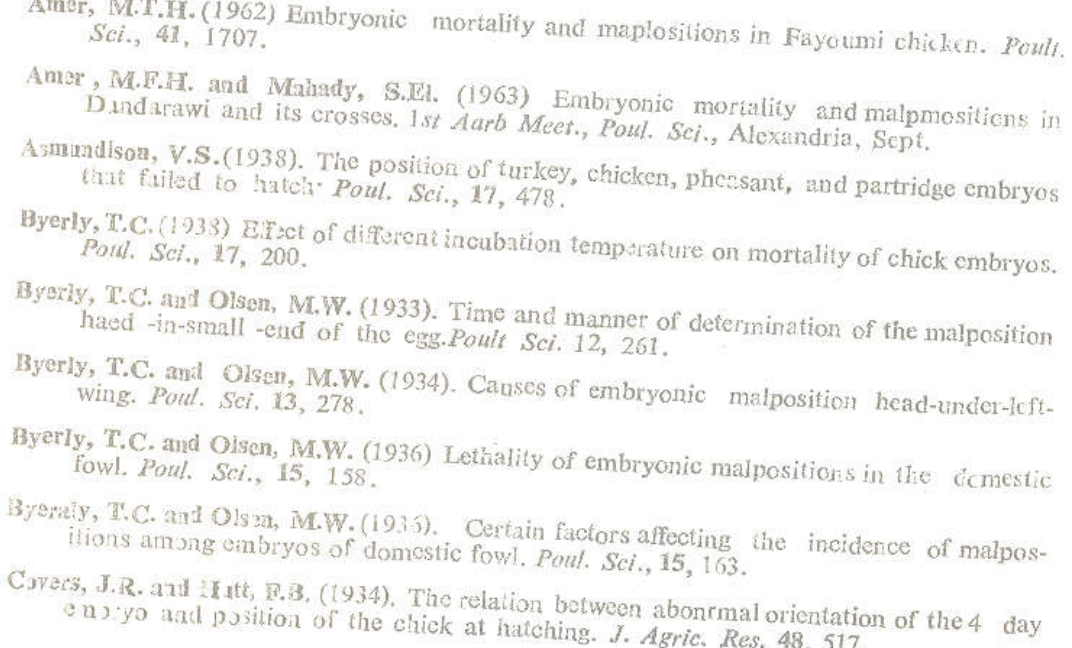

Egypt. J. Anim. Prod. 24, No. 1-2 (1984) 
Holmy, S.A.(1958) Furtility, embryonic mortality and hatchability in poultry as affected by ginetical environmental and physical factors.Ph.D. Thesis., Faculty of Agriculture Ctiro Unaiversily.

Hasgendiorin, J. (1955) Malposition of the chicks in the egg. Rev. Ele. Prod., Amin. France 10, 741 (C.F.A.B.A. 24.349).

Hutt, F.B. (1929) Studies on embryonic mortality in the fowl. I. The frequencies of variosmalpositions of the chick embryo and their significance. Proceedings of the Royal so, of Elinbargh, 49, 118-(C.F. Landauer, 1951).

Hutt, F.B.(1938) Embryonic mortality in fowl.VIX. On the relation of malposition to the sizo and shupe of egg3. Poul. Sci., 17. 245.

Hutt, F.B. and Cavers, J.R.(1931). The lethal nare of certain malpositions of the chick embryo. Pousl. Sci., 10 ,

Huut, F.B. and Pilkey, A.M. (1934) Studies in embryonic mortality in the fowl. V. Relation ship batwsen positions of the eggs and frequencies of malpositions. Poul. Sci. 13, 3

Insko, J.R. W.M. and Martin, J.M.(1933) Effect of frequent turning on hatchability and distribution of embryo mortality. Powl. Sci. 12, 282.

Landauer, W. (1948) The hatchability of chicken eggs as influenced by environment and heredity. Storrs. Agric. Esp. Stat. Bull. No. 262.

Olsen, M.W. and Byerly, T.C. (1936) Multiple turning and orienting eggs during incubation as they affect hatchability. Poul. Sci., 15, 88 .

Sanctuary, W.C. (1924-1925) One cause of dead chicks in the shell. Pout. Sci. 4,141.

Smith, J.B. (1931) Malpositions-a factor in hatchability. Proceeding of the twenty second annual meeting. Poul. Sci. Assoc., 1930, 1931, PP. 66.

Siedecor, G.W. (1956) "Statistical Methods", 5 th Ed. Lawa State College Press, Ames, Jawa.

Visschedijk, A.H.J. and Kuper, J.W. (1955) Malposition of the embryo in hens eggs. Arch. Geffigel, 19, 73. (C.F. A.B.A. 24 365).

Waters, N.F. (1935) Changes in the position of chick embryos after the eighteenth day of incubation. Science, 82, 66-(C.F. Landauer, 1951).

Egypt. J. Anim. Prod. 24, No. 1-2 (1984) 


\section{الأوضساع المثاذة في ميض البط المبكينى}

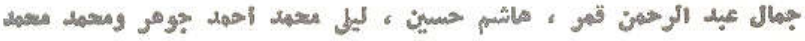

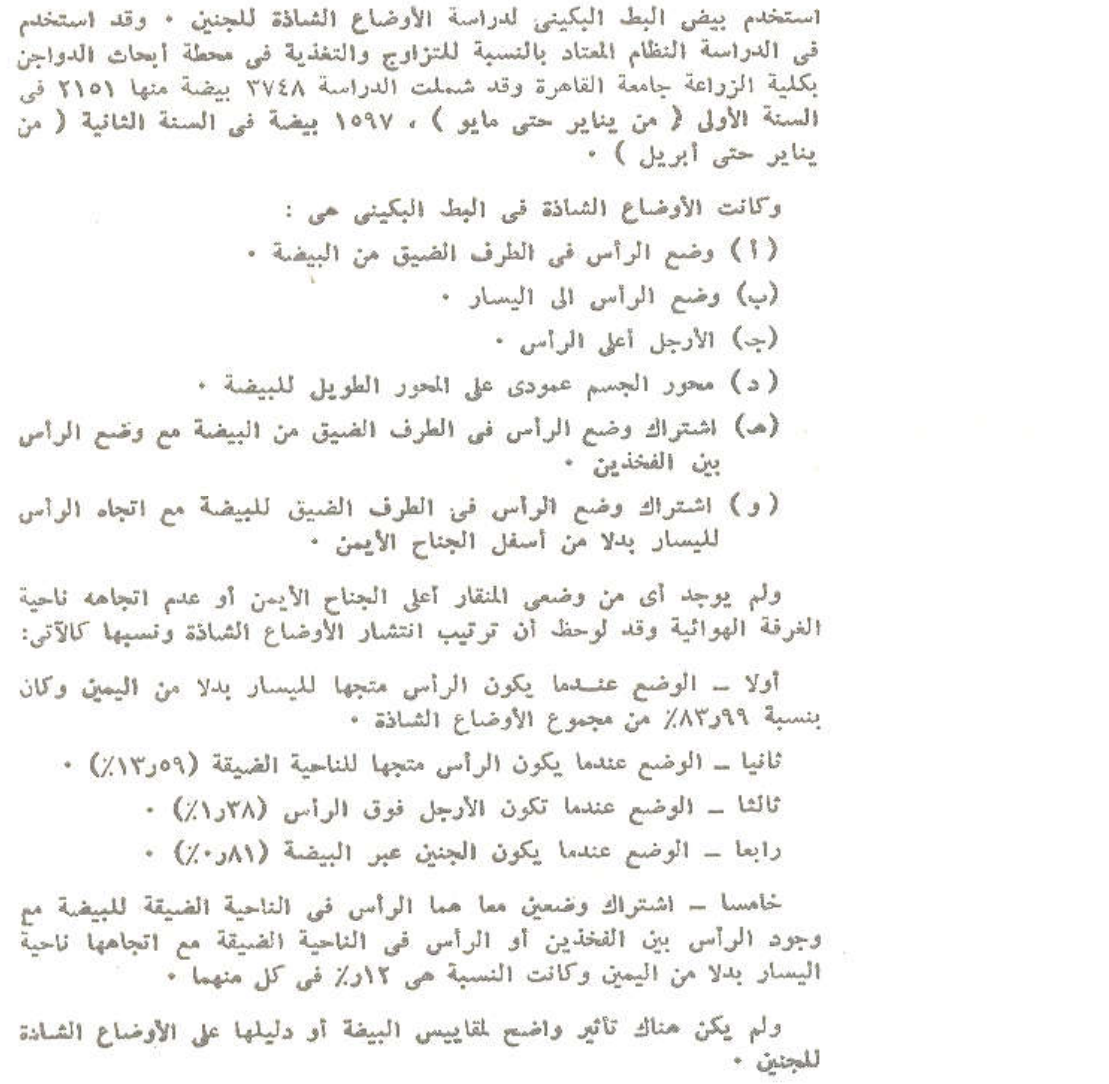

